\title{
Valuable Fatty Acids in Bryophytes-Production, Biosynthesis, Analysis and Applications
}

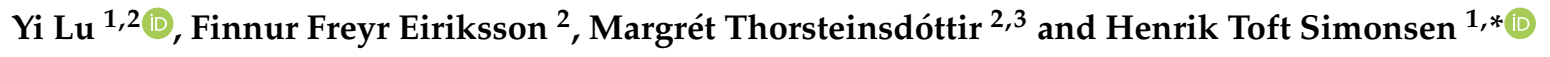 \\ 1 Department of Biotechnology and Biomedicine, Technical University of Denmark, Søltofts Plads 223, \\ 2800 Kongens Lyngby, Denmark; yilu@dtu.dk \\ 2 ArcticMass, Sturlugata 8, 101 Reykjavik, Iceland; finnur@arcticmass.is (F.F.E.); margreth@hi.is (M.T.) \\ 3 Faculty of Pharmaceutical Sciences, University of Iceland, Hagi, Hofsvallagata 53, 107 Reykjavik, Iceland \\ * Correspondence: hets@dtu.dk; Tel.: +45-26-98-66-84
}

Received: 20 September 2019; Accepted: 16 November 2019; Published: 19 November 2019

\begin{abstract}
Bryophytes (mosses, liverworts and hornworts) often produce high amounts of very long-chain polyunsaturated fatty acids (vl-PUFAs) including arachidonic acid (AA, 20:4 $\Delta 5,8,11,14$ ) and eicosapentaenoic acid (EPA, 20:5 $\Delta 5,8,11,14,17)$. The presence of vl-PUFAs is common for marine organisms such as algae, but rarely found in higher plants. This could indicate that bryophytes did not lose their marine origin completely when they landed into the non-aqueous environment. Vl-PUFA, especially the omega-3 fatty acid EPA, is essential in human diet for its benefits on healthy brain development and inflammation modulation. Recent studies are committed to finding new sources of vl-PUFAs instead of fish and algae oil. In this review, we summarize the fatty acid compositions and contents in the previous studies, as well as the approaches for qualification and quantification. We also conclude different approaches to enhance AA and EPA productions including biotic and abiotic stresses.
\end{abstract}

Keywords: arachidonic acid; bryophytes; eicosapentaenoic acid; environmental stress; polyunsaturated fatty acid

\section{Introduction}

Bryophytes are an informal group of three divisions of non-vascular land plant, which consist of about 25,000 known species globally. They are divided into mosses (Bryophyta, 18,000 species), liverworts (Marchantiophyta, 6000 species) and hornworts (Anthocerotophyta, 1000 species) [1]. Bryophytes are amphibian plants, which are found in almost all kinds of habitats world-wide, from dry desert to humid rainforest, from hot tropical area to the cold Arctic and from sea level to alpine peaks [2]. Bryophytes are taxonomically important as they are believed to represent a close connection between aquatic lives to land organisms [3]. Liverworts are probably the earliest land plants, which are believed to be the first landed plant, almost 500 million years ago [4,5].

In general, bryophytes show high tolerance against various biotic and abiotic stresses [6,7]. Unlike higher plants, bryophytes do not have a vascular system and lack thick waxy cutin protection on the cell walls [8], they defend themselves by producing several specialized metabolites instead. This can explain why bryophytes are rarely consumed by insects and herbivores, not only because bryophytes have low caloric content but also for the diversity of "chemical weapons" they produce $[9,10]$. Besides, bryophytes have a high desiccation tolerance and freezing tolerance, which allow them to survive in dry surroundings or in cold temperatures and recover rapidly afterwards [11].

The chemical composition of bryophytes, from macro-compounds (carbohydrates, proteins and lipids) [12] to specific substance groups such as fatty acids (FAs) [13-15], terpenoids [1,16,17], flavonoids [1] and polyphenols [18], have already been studied. 
However, when compared to algae and higher plants, the phytochemistry of bryophytes is still poorly understood, possibly because they are morphologically small, and it is also difficult to collect pure samples in large quantities. Alongside the small quantities of material, elimination of all accompanying materials (e.g., dead tree leaves, soil, twigs, even small animals) can be difficult [19]. A possible method to obtain large bryophyte biomass is to grow them in liquid culture in bioreactors. Several in vitro cultivations have been applied on over 300 mosses and 50 liverworts [20], though one has to put a lot of effort into this, in order to obtain purely axenic cultures [21].

Among all metabolites in bryophytes, lipids are considered to be one of the most important groups, as they play many vital roles in energy storage, membrane formation, cell signaling, functioning and environmental adaption [22]. The content of lipids ranges from 1 to $9.1 \%$ of dry weight depending on the region and growth condition [23]. In general, lipids refer to all non-hydrophilic compounds, including free fatty acids, triglycerides, glycolipids, phospholipids, sterols, wax esters, fatty alcohols and terpenoids. These lipophilic chemical constituents could be the reason that bryophytes have been used in many countries as ethno-medicine for the treatment of cuts, burns and bruises because of their anti-fungal, anti-inflammatory and anti-oxidant functions $[1,10,24-26]$. The genera Sphagnum, Marchantia and Polytrichum are the most widely used bryophytes worldwide [24], mostly in China, followed by USA and Canada [24], whereas Physcomitrella patens is the only one used for industrial biotechnological purposes $[11,27,28]$. Recent in vivo experiments [29] also tested the antifeedant and anti-fungal activities of extracts from several bryophytes species, indicating a potential value of a promising biopesticide from bryophytes for the replacement of synthesized pesticides. This has already been sold as a commercial product in Germany [30]. The important biologically-active compounds from bryophytes are mainly terpenoids and phenylpropanoid- derived compounds, such as polyphenol and flavonoids. As for the terpenoids, most studies have worked with liverworts because of the presence of oil bodies, where the terpenoids are stored [6]. More than 1600 terpenoids have been identified from liverworts [1]. Currently there are already several reviews on terpenoids [1,16,31-33] and phenylpropanoid-derived-compounds [10,31], where the chemical structures of these compounds and their biological activities are explained.

Very long chain polyunsaturated fatty acids (vl-PUFAs) have received a lot of interest in recent years due to their health-promoting effect in humans and livestock [34,35]. Bryophytes produce high contents of arachidonic acid (AA, 20:4, $\Delta 5,8,11,14)$ and eicosapentaenoic acid (EPA, 20:5, $\Delta 5,8,11,14,17)$, which are uncommon in higher plant. This suggests that bryophytes are genetically closer to algae rather than other terrestrial plants [36]. Their high $\omega-3 / \omega-6$ ratio also suggest an alternative and sustainable approach to improve human vl-PUFAs intake by inserting high-PUFAs-bryophyte-genes in order to modify current oilseed genes [37]. Most of the studies in this field have been focused on the model moss species P. patens [38] and common liverwort Marchantia polymorpha [39], which are the two species with complete genome sequences that have been published in bryophytes.

In this review, we only focus on fatty acids and their linked lipid classes in bryophytes. The purpose of this review is to summarize the production of fatty acids and the accumulation of AA and EPA under various stress conditions in bryophytes from recent published studies. Furthermore, this review also presents strategies for the identification and quantification of fatty acids in bryophytes. Finally, we wish to highlight the potential use of bryophytes as new sources for vl-PUFAs.

\section{Fatty Acid Biosynthetic Pathways}

A brief biosynthetic pathway of major fatty acids produced by bryophytes is shown in Figure 1 . Acetyl-CoA and malonyl-CoA are the basic building blocks for fatty acid biosynthesis, followed by a series of reactions by fatty acyl synthases. Acyl carrier proteins (ACPs) carry the intermediates during the fatty acid elongation. The emerging chain is elongated through six cycles to reach the primary product palmitic acid (16:0), and a small amount of shorter chain fatty acids may be released before reaching 16 carbons in length or breakdown products. After releasing from plastid, linoleic acid (LA,18:2, $\Delta 9,12, \omega-6)$ serves as a precursor of a family of PUFAs, which is formed by desaturation and 
chain elongation [22]. Plants, including bryophytes, can synthesize $\alpha$-linolenic acid (ALA, $\Delta 9,12,15$, $\omega-3)$ from LA catalyzed by $\Delta 15$ desaturase. Alternatively, LA can also be converted by $\Delta-6$ desaturase to $\gamma$-linolenic acid (GLA, 18:3, $\Delta 6,9,12), \Delta$-6 elongase to di-homo $\gamma$-linolenic acid (DGLA, 20:3, $\Delta 8,11,14$ ) and $\Delta-5$ desaturase to AA ( $\omega-6)$. The enzymes, $\Delta 5$ - and $\Delta-6$ desaturases are responsible for LA and ALA unsaturation, while the enzyme $\Delta-6$ elongase is responsible for the elongation of C18 fatty acids to $C 20$ fatty acids. $\Delta-6$ desaturase, $\Delta-6$ elongase and $\Delta-5$ desaturase are the keys for high PUFAs production in bryophytes, since they are not expressed in higher plants [40].

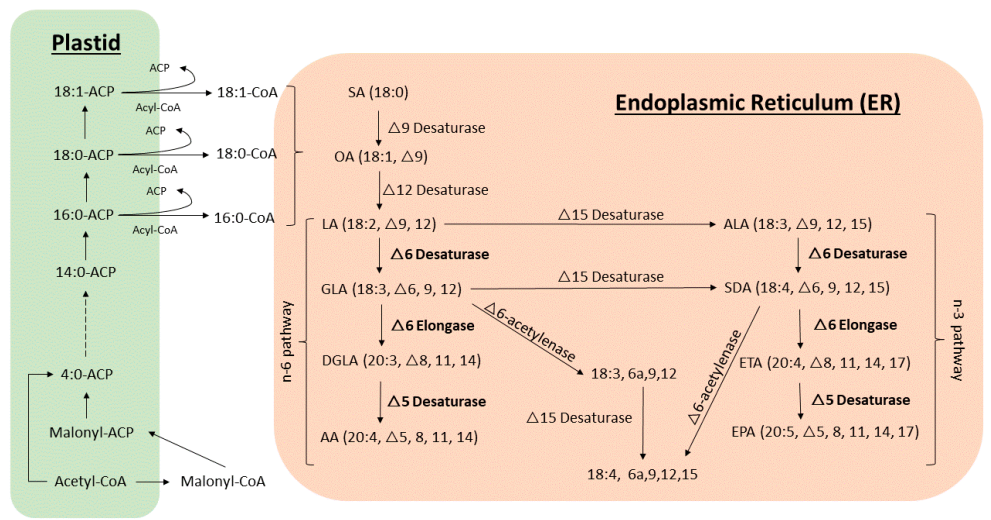

Figure 1. An overview of PUFAs and acetylenic fatty acids synthetic pathways in bryophytes. Fatty acids biosynthesis starts from a consecutive attachment of two carbon units until 16:0, 18:0 and 18:1 in plastid, where the fatty acids are attached to the Acyl carrier protein (ACP), and some enzymes that terminate the chain-elongation early, resulting in the production of fatty acids with shorter chains. 16:0, 18:0 and 18:1 are further transferred to the endoplasmic reticulum (ER) for PUFAs production by several fatty acid desaturases. Some unusual occurrence of acetylenic acids are also synthesized in ER. SA, stearic acid; OA, oleic acid; LA, linoleic acid; GLA, $\gamma$-linolenic acid; DGLA, di-homo $\gamma$-linolenic acid; AA, arachidonic acid; ALA, $\alpha$-linolenic acid; SDA, stearidonic acid; ETA, eicosatetraenoic acid; EPA, eicosapentaenoic acid.

In addition to common FAs, odd-chain FAs were found in trace amounts in bryophytes, which may be synthesized when fatty acid synthase accepts propionyl-CoA instead of acetyl-CoA as a primer molecule or when alpha-oxidation of FAs occurs [41].

\section{Analysis of Fatty Acids in Bryophytes}

Different lipid analysis methods have been developed and evaluated on several bryophyte species in the past few decades. To investigate the composition of fatty acids and their linked lipid classes such as neutral lipids (NLs), polar lipids (PLs) or glycolipids (GLs), a step of lipid separation (or purification) is usually performed using thin layer chromatography (TLC) to yield different lipid fractions. Solid phase extraction (SPE) is also a well-developed method for lipid separation, solvents with different polarities are used for separating different lipid classes [42]. Klavina and Kviesis (2015) used the SPE column to separate different groups of lipids in moss Polytrichum commune and Dicranum polysetum by using hexane for the extraction of alkanes, sterols, the fatty alcohols; hexane/chloroform (5:1), for the extraction of esters, ketones, aromatic substances; and chloroform for extraction of sterols [43].

Since most of the studies in bryophytes have been focusing on volatile specialized metabolites, most of the chemical analyses is performed on gas chromatography-flame ionization detector (GC-FID) and gas chromatography-mass spectrometry (GC-MS) (Table 1). These techniques require relatively large quantities of samples that have to be cleaned from other interfering materials. The cleaning process for bryophytes is time-consuming compared with other plants, as they grow in between each other and other organisms. Thus, obtaining grams of "pure" species is long and tedious work. The need of derivatization and limited resolution along with difficulties in the identification of fatty 
acids and their isomers also lead to adjacent masses and peak interference [44]. Thus, the development of a new method for bryophyte lipid analysis, a method which only requires milligrams of fresh material, is of great importance. The emerging field in lipidomics is a new platform for lipid-related metabolic pathways in plants. Screening of biomarkers by untargeted lipid analysis using liquid chromatography-mass spectrometry (LC-MS), allows for the separation and identification of possible lipophilic compounds and derivatives in biological samples. It is a powerful tool to evaluate the phylogenetic diversity among different species [45] and examine the change of related lipid species due to environmental variability [46]. The lipid extract can also be injected directly to electrospray ionization triple quadrupole mass spectrometry (ESI-MS/MS), which has a great advantage on analyzing the formation of PLs in plants [46]. Matrix-assisted laser desorption/ionization time-of-flight mass spectrometry (MALDI-TOF-MS) is another analytical technique that has good sensitivity and reproducibility for analyzing plant endogenous molecules [47] and for a rapid screening of free FAs in biological samples from different origins [48]. Generally, LC-based lipidomics is relatively rapid and usually requires less sample than GC-derived methods, since only $2-10 \mathrm{mg}$ of leaf dry weight is needed. So far, lipid profiling has been performed on a large variety of plants such as Arabidopsis thaliana [49], and several algae species such as the snow alga Chlamydomonas nivalis [50], the diatom Nitzschia Closterium [51] and the brown alga Sargassum horneri [52], but these advanced techniques have not yet been applied on bryophytes.

Table 1. Methods used for characterization and quantification of lipids in bryophytes.

\begin{tabular}{|c|c|c|c|c|}
\hline Species & Lipid Types & Methods & Derivatization & References \\
\hline Mnium cuspidotum & FAs & $\begin{array}{l}\text { TLC for purification, GC } \\
\text { for quantification }\end{array}$ & $\begin{array}{c}\text { Alkylation } \\
\text { (diazomethane) }\end{array}$ & [53] \\
\hline Ceratodon purpureus & FAs & $\begin{array}{l}\text { GC for purification, } \\
\text { Mass spectrometry for } \\
\text { molecular weight, UV } \\
\text { and IR for structural } \\
\text { confirmation }\end{array}$ & $\begin{array}{c}\text { Alkylation } \\
\text { (diazomethane) }\end{array}$ & [54] \\
\hline 38 moss species & FAs & $\begin{array}{l}\text { TLC for purification and } \\
\text { identification. GC-MS } \\
\text { for FAs analysis }\end{array}$ & $\begin{array}{c}\text { Alkylation } \\
\text { (methylation) }\end{array}$ & [55] \\
\hline Riccia fluitans & FAs & $\begin{array}{c}\text { GC for purification, FAs } \\
\text { analysis by GC-MS, } \\
\text { NMR }\end{array}$ & $\begin{array}{l}\text { Alkylation } \\
\text { (methylation) }\end{array}$ & [56] \\
\hline $\begin{array}{l}\text { Twelve liverworts in genus } \\
\text { Riccia }\end{array}$ & FAs & $\begin{array}{l}\text { TLC for purification and } \\
\text { identification, GC-MS for } \\
\text { analysis }\end{array}$ & $\begin{array}{l}\text { Alkylation } \\
\text { (methylation) }\end{array}$ & [57] \\
\hline $\begin{array}{c}\text { Eurhynchium striatum, } \\
\text { Brachythecium rutabulum, } \\
\text { Brachythecium salebrosum, } \\
\text { Scleropodium purum, } \\
\text { Rhytidiadelphus squarrosus and } \\
\text { Rhytidiadelphus triquetrus }\end{array}$ & $\begin{array}{l}\text { FAs (from NL, GL, } \\
\text { PL and TL) }\end{array}$ & $\begin{array}{l}\text { HPTLC for NL, PL and } \\
\text { GL separation, GC-FID } \\
\text { for FA analysis }\end{array}$ & $\begin{array}{l}\text { Acylation (acetyl } \\
\text { chloride) }\end{array}$ & [58] \\
\hline $\begin{array}{l}\text { Rhytidiadelphus squurrosus and } \\
\text { Eurhynchium striatum }\end{array}$ & FAs & GC-FID & $\begin{array}{l}\text { Trimethylsilylation } \\
\text { (Triphenylmethanol) }\end{array}$ & [59] \\
\hline 55 species of Bryophyta & FAs on MGDG & $\begin{array}{l}\text { TLC for separation, GC } \\
\text { for FAs analysis }\end{array}$ & - & {$[60]$} \\
\hline $\begin{array}{l}\text { Marchantia polymorpha, } \\
\text { Atrichum angustatum and } \\
\text { Brachythecium } \mathrm{sp} .\end{array}$ & $\begin{array}{c}\text { FAs (from TL, NL, } \\
\text { PL, GL) }\end{array}$ & $\begin{array}{l}\text { TLC for separation, } \\
\text { GC-MS for FAs analysis }\end{array}$ & Silylation & {$[61]$} \\
\hline $\begin{array}{c}\text { Calliergon cordifolium, } \\
\text { Drepanocladus lycopodioides, } \\
\text { Fontinalis antipyretica and } \\
\text { Riccia fluitans }\end{array}$ & $\begin{array}{l}\text { FA (fromTL, TAG, } \\
\text { PL, GL) }\end{array}$ & $\begin{array}{c}\text { TLC for separation, } \\
\text { GC-MS for FAs analysis }\end{array}$ & Silylation & {$[62]$} \\
\hline
\end{tabular}


Table 1. Cont.

\begin{tabular}{|c|c|c|c|c|}
\hline Species & Lipid Types & Methods & Derivatization & References \\
\hline Marchantia polymorpha & $\begin{array}{l}\text { FAs (from NL, GL, } \\
\text { PL) }\end{array}$ & $\begin{array}{l}\text { TLC for separation, } \\
\text { HPLC with fluorescence } \\
\text { detection }\end{array}$ & No derivatization & [63] \\
\hline Marchantia polymorpha & FAs & GC-FID & $\begin{array}{c}\text { alkylation } \\
\left(\mathrm{BF}_{3} \text {-methanol }\right.\end{array}$ & [64] \\
\hline Marchantia polymorpha & FAs & GC-MS & $\begin{array}{l}10 \% \text { methanolic } \\
\mathrm{HCl})\end{array}$ & [40] \\
\hline Marchantia polymorpha & FAs & GC & Alkylation & [65] \\
\hline Physcomitrella patens & FAs & GC-FID & $\begin{array}{c}\text { Alkylation } \\
\text { (methylation) }\end{array}$ & [66] \\
\hline $\begin{array}{l}\text { Homomallium connexum, } \\
\text { Actinothuidium hookeri and } \\
\text { Neckera pennata }\end{array}$ & $\begin{array}{l}\text { FAs (only carbon } \\
\text { number) }\end{array}$ & $\begin{array}{l}\text { HPLC with fluorescence } \\
\text { detection, } \mathrm{APCI} / \mathrm{MS} \text { for } \\
\text { determination }\end{array}$ & $\begin{array}{c}\text { Alkylation } \\
\text { (N,N-dimethyl-formamide) }\end{array}$ & e) ${ }^{[67]}$ \\
\hline Rhodobryum ontariense & FAs & GC-MS, NMR & $\begin{array}{c}\text { Alkylation } \\
\text { (methylation) }\end{array}$ & [68] \\
\hline $\begin{array}{c}\text { Atrichum undulatum and } \\
\text { Hypnum andoi }\end{array}$ & FAs & GC-FID and GC-MS & $\begin{array}{l}\text { Alkylation } \\
\text { (methylation) }\end{array}$ & [69] \\
\hline $\begin{array}{l}\text { Physcomitrella patens, Encalypta } \\
\text { streptocarpa, Pottia lanceolata, } \\
\text { Plagiomnium undulatum, } \\
\text { Atrichum undulatum, } \\
\text { Brachythecium rutabulum and } \\
\text { Rhynchostegium murale }\end{array}$ & FAs & GC-MS & $\begin{array}{c}\text { Alkylation } \\
\text { (methylation) }\end{array}$ & [13] \\
\hline $\begin{array}{l}\text { Polytrichum commune and } \\
\text { Dicranum polysetum }\end{array}$ & $\begin{array}{l}\text { FAs and other } \\
\text { hydrophobic } \\
\text { compounds }\end{array}$ & $\begin{array}{l}\text { SPE for separation, } \\
\text { GC-MS for identification }\end{array}$ & $\begin{array}{l}\text { Silylation } \\
\text { (N,O-Bis(trimethylsilyl)- } \\
\text { trifluoroacetamide) }\end{array}$ & [43] \\
\hline Anisothecium spirale & Free FAs, TAG & $\begin{array}{l}\text { HP-TLC for lipids } \\
\text { separation, GC-FID and } \\
\text { GC-MS for quantification }\end{array}$ & $\begin{array}{c}\text { Alkylation } \\
\text { (methylation) }\end{array}$ & [70] \\
\hline
\end{tabular}

Abbreviations: HPLC, High-performance liquid chromatography; APCI, Atmospheric pressure chemical ionization; NMR, Nuclear magnetic resonance.

\section{Fatty Acids Present in Bryophytes}

FAs are usually present as part of membrane phospho- and glycolipids, or as constituents in triacylglycerides (TAGs); healthy living bryophytes tissue do not normally accumulate free FAs [71]. FAs from bryophytes, including saturated, mono-, poly-unsaturated and acetylenic fatty acids (AFAs) are listed in Table 2. Similar to the other plants and organisms, bryophytes can synthesize some common saturated fatty acids such as palmitic acid (16:0) and stearic acid (18:0). Medium-chain fatty acids, such as lauric acid (12:0) and myristic acid (14:0) are also found in a limited amount. Some odd-chain saturated fatty acids, pentadecanoic acid (15:0) and margaric acid (17:0), which do not commonly appear in nature, can also be found in trace amounts in some bryophytes. Several monoand polyunsaturated fatty acids, such as oleic acid (OA, 18:1, $\Delta 9)$, LA and ALA are abundant in all bryophytes species. Long-chain- and very-long-chain fatty acids (C20 and above) are rarely produced by higher plant, but high amount of vl-PUFAs, AA and EPA in particularly, are commonly found in bryophytes. High contents of PUFAs are important for bryophytes to survive under low temperature and harsh environment [72], where some bryophytes can even survive at $-14{ }^{\circ} \mathrm{C}$ [73]. These differences are of great importance to distinguish bryophytes from other higher plants.

The vl-PUFAs, especially $\omega$-3 PUFAs, are essential for human health as they play an important role in eicosanoids synthesis (e.g., prostaglandins, thromboxanes, leukotrienes and lipoxins), cell signaling and gene expression [34]. Humans de novo synthesize LA and ALA with very low synthetic efficiency, therefore we must obtain these essential fatty acids from food [74]. Although bryophytes are not an ideal source for food consumption due to the poor nutrient content [9], this unique metabolism 
of bryophytes can still indirectly benefit human by optimizing $\omega-3$ oil production in seed crops by a transgenic approach [37].

AFAs are extensively found in some bryophyte families. Many studies show that AFAs appear as part of triacylglycerol to maximize energy conservation when growth space is limited [23]. The uncommon AFA Dicranin (octadeca-6-yn-9, 12, 15-trienoic acid, 18:4a) is almost found exclusively in the Dicranaceae family. Several studies showed high AFA contents in Dicranaceae species $[55,70,75]$. In particularly, $72.1 \%$ of AFA of total fatty acid was found in Dicranum polysetum [76], of which Dicranin was the predominant AFA with $23.5 \%$ of total fatty acids.

AFAs appear to have pharmaceutical properties, and the moss Rhodobryum was used as traditional Chinese medicine to treat cardiovascular diseases, possibly due to the richness of ALA and Dicranin [68]. Likewise, ALA is also a precursor of some acetylenic oxylipins, which act as defense compounds against bacteria, fungi and insects [77]. 
Table 2. Fatty acids composition in bryophytes.

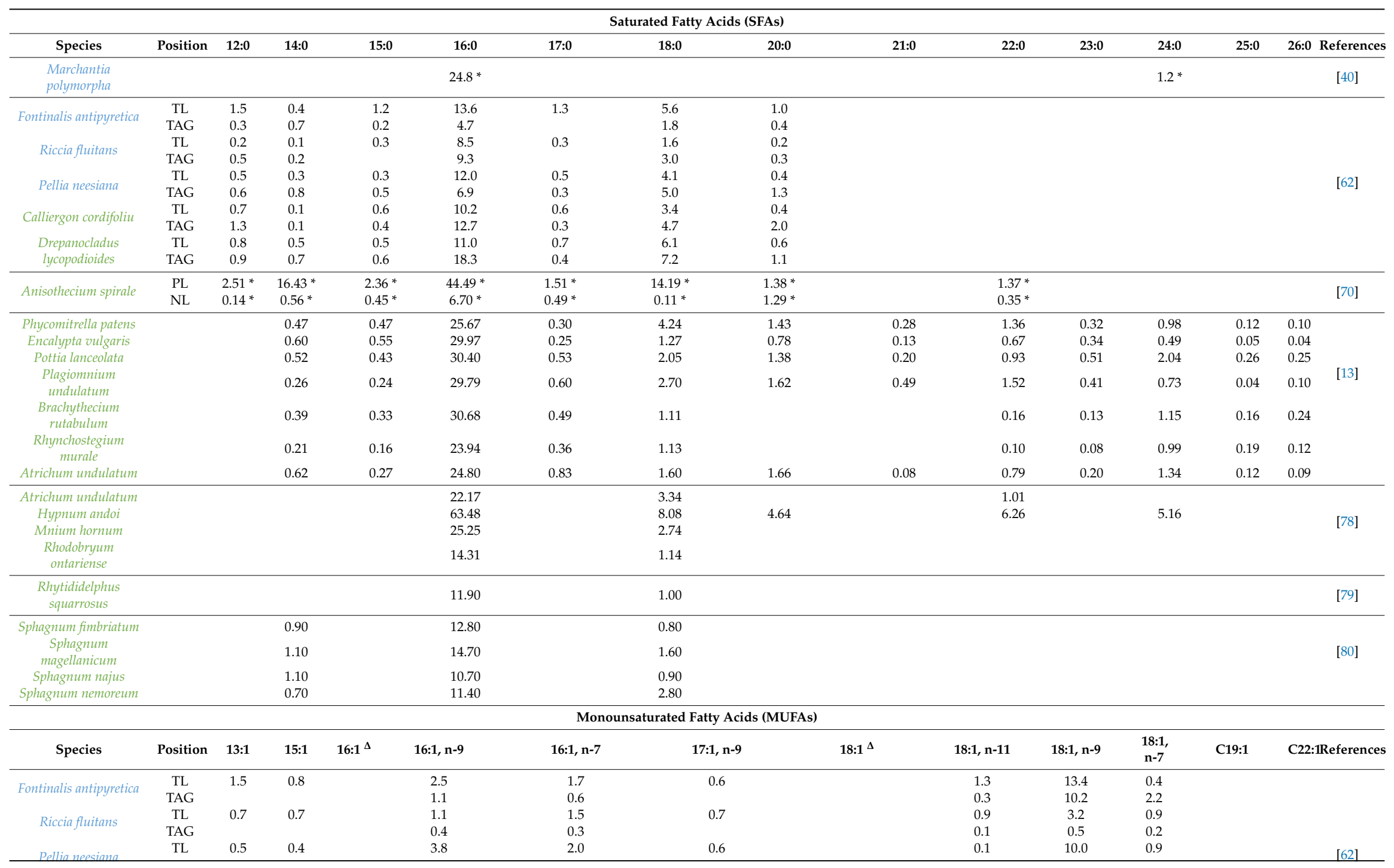


Table 2. Cont.

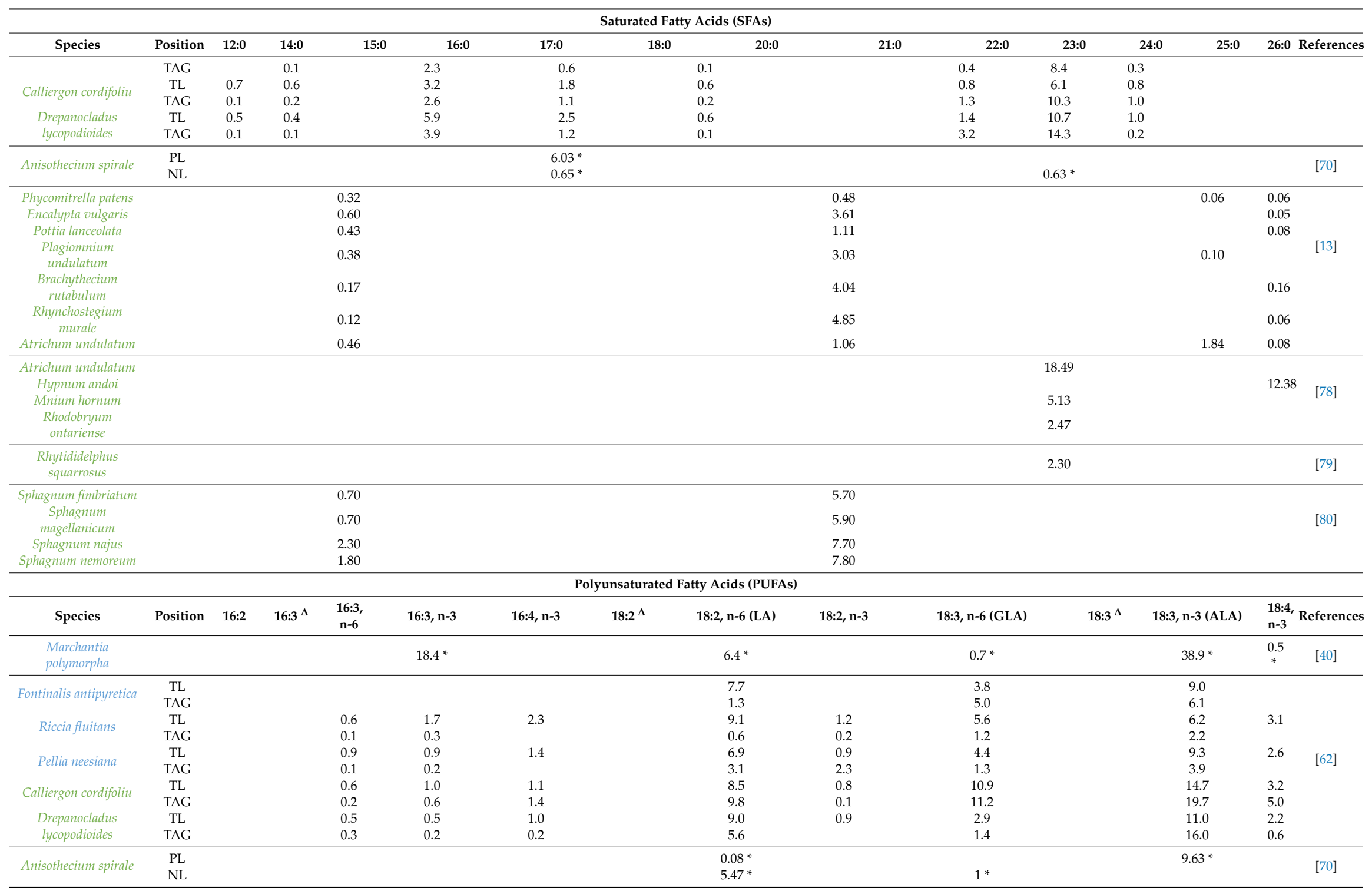


Table 2. Cont.

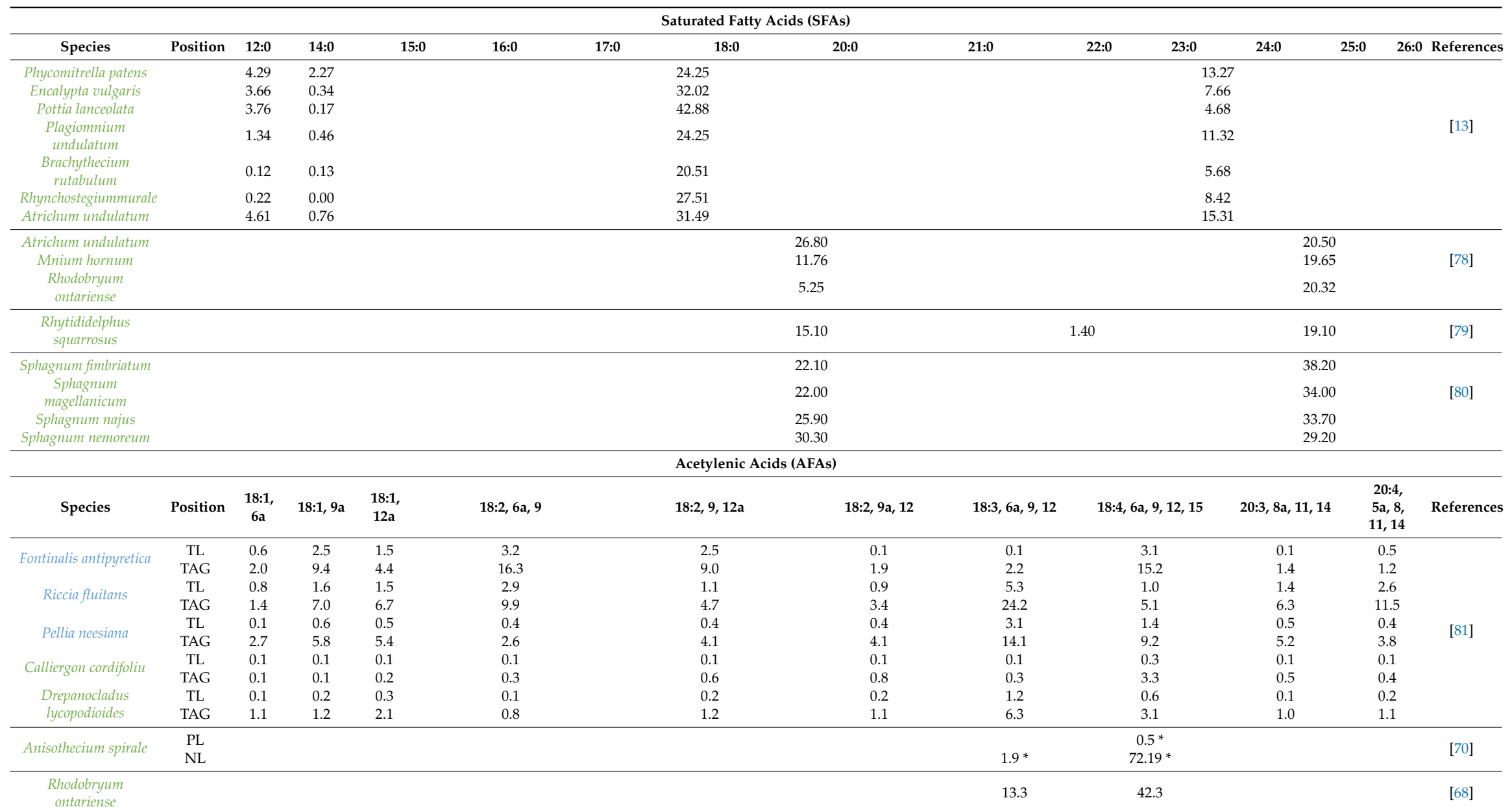

Abbreviations: PL, Polar lipid; NL, Neutral lipid; TL, Total lipid; TAG, Triacylglycerol; Unit: \% of total FAs. ${ }^{*}$ mol\% of total FA. ${ }^{\Delta}$ fatty acids with no specific positional information. Species in blue are liverworts whereas mosses are in green. The fatty acid composition and content are very much depending on the growth condition, this table summarizes information from various conditions, and therefore it is only considered as a guidance. 


\section{Arachidonic Acid (AA) and Eicosapentaenoic Acid (EPA)}

AA and EPA are rarely found in higher plants [82], however they are both common in bryophtyes. AA and EPA are precursors for the biosynthesis of some eight-carbon fragrant fatty alcohol, such as 1-octen-3-ol, octan-3-one and octan-3-ol, in damaged M. polymorpha [83]. Mosses and liverworts with high contents of AA and EPA in proportion to total lipid are shown in Table 3.

Table 3. Bryophytes species with high contents of AA and EPA.

\begin{tabular}{|c|c|c|c|c|c|}
\hline Species & Tissues & Regions & AA Contents * & EPA Contents * & References \\
\hline Eurhynchium striatum & \multirow{6}{*}{ Gametophyte } & \multirow{6}{*}{ Switzerland } & 36.7 & 10.8 & \multirow{12}{*}{ [58] } \\
\hline $\begin{array}{l}\text { Brachythecium } \\
\text { rutabulum }\end{array}$ & & & 23.5 & 23.4 & \\
\hline $\begin{array}{l}\text { Brachythecium } \\
\text { salebrosum }\end{array}$ & & & 20.9 & 15.0 & \\
\hline Scleropodium purum & & & 29.0 & 8.6 & \\
\hline $\begin{array}{l}\text { Rhytidiadelphus } \\
\text { squarrosus }\end{array}$ & & & 24.0 & 14.9 & \\
\hline $\begin{array}{l}\text { Rhytidiadelphus } \\
\text { triquetrus }\end{array}$ & & & 24.6 & 9.5 & \\
\hline Eurhynchium striatum & \multirow{6}{*}{ Protonema } & \multirow{6}{*}{$\begin{array}{c}\text { Collected in } \\
\text { Switzerland then } \\
\text { keep in cell culture }\end{array}$} & 33.6 & 2.7 & \\
\hline $\begin{array}{l}\text { Brachythecium } \\
\text { rutabulum }\end{array}$ & & & 40.1 & 4.7 & \\
\hline $\begin{array}{l}\text { Brachythecium } \\
\text { salebrosum }\end{array}$ & & & 32.2 & 4.9 & \\
\hline Scleropodium purum & & & 41.5 & 2.6 & \\
\hline $\begin{array}{l}\text { Rhytidiadelphus } \\
\text { squarrosus }\end{array}$ & & & 32.4 & 5.2 & \\
\hline $\begin{array}{l}\text { Rhytidiadelphus } \\
\text { triquetrus }\end{array}$ & & & 20.0 & 1.7 & \\
\hline $\begin{array}{l}\text { Marchantia } \\
\text { polymorpha }\end{array}$ & & Cell culture & 11 & 3 & [63] \\
\hline $\begin{array}{l}\text { Marchantia } \\
\text { polymorpha }\end{array}$ & & Cell culture & $2.2^{+}$ & $2.6^{+}$ & [14] \\
\hline $\begin{array}{l}\text { Marchantia } \\
\text { polymorhpa }\end{array}$ & & Agar plate, WT & $3.1^{\#}$ & $5.9^{\#}$ & {$[40]$} \\
\hline Leptobryum pyriforme & Protonema & Cell culture & 20 & 7 & [84] \\
\hline \multirow{2}{*}{ Physcomitrella patens } & Gametophores & \multirow{2}{*}{ Cell culture } & 18.7 & 1.5 & \multirow{3}{*}{ [13] } \\
\hline & Protonema & & 15.9 & 6.8 & \\
\hline $\begin{array}{l}\text { Rhynchostegium } \\
\text { murale }\end{array}$ & Gametophores & Cell culture & 26.4 & 3.5 & \\
\hline Mnium cuspidatum & Gametophores & Minnesota & 11.4 & 8.9 & \multirow{4}{*}{ [85] } \\
\hline Mnium medium & Gametophores & Minnesota & 23.0 & 19.0 & \\
\hline Hylocomium splendens & Gametophores & Alaska & 12.9 & 18.3 & \\
\hline Pleurozium schreberi & Gametophores & Alaska & 29.0 & 11.0 & \\
\hline $\begin{array}{l}\text { Rhytididelphus } \\
\text { squarrosus }\end{array}$ & Gametophores & Germany & 30.7 & 14.4 & [86] \\
\hline Atrichum undulatum & & Germany & 6.21 & 1.52 & [69] \\
\hline Mnium hornum & & & 26.03 & 9.44 & [78] \\
\hline Anisothecium spirale & Gametophyte & Eastern Himalayas & $1.09^{\#}$ & $0.27^{\#}$ & {$[70]$} \\
\hline
\end{tabular}


VL-PUFAs are essential for human, since they are the main constituents of human brain phospholipids, and can prevent cardiovascular diseases [34]. Human cannot synthesize ALA ( $\omega-3)$ from its precursor LA ( $\omega-6)$, since we do not have $\Delta-15$ desaturase, thus, $\omega-3$ and $\omega-6$ fatty acids imbalance is an unignorably problem of human health [35]. Extra $\omega-3$ PUFAs such as EPA and DHA are often taken as daily supplements derived from fish oils. However, the accumulation of heavy metals and reduced production of marine fish make it an unsustainable source of $\omega$-3 vl-PUFA [74]. Consequently, the development of other sources for $\omega-3$ vl-PUFA is in urgent need. A novel, affordable and renewable approach is to transfer the $\omega-3$ vl-PUFA-expressed-genes to oilseed crops by using transgenic engineering [37]. High accumulation of AA (1.6\%) and EPA (2.7\%) were observed in linseed oil when $\Delta 5, \Delta 6$ desaturases from the diatom Phaeodactylum tricornutum and $\Delta 6$ elongases from P. patens were successfully expressed in linseed [87]. The same three genes from liverwort $M$. polymorpha were introduced into tobacco, which resulted in a production of $15.5 \%$ AA and $4.9 \%$ EPA of total fatty acids in the leaves [40]. This shows that there is a huge potential for a new source of vl-PUFAs for human consumption in addition to fish oil, although no commercial product is available in the market now.

\section{Strategies of Enhancing the Production of vl-PUFAs}

Only a small proportion of bryophytes species have been examined for their fatty acid composition, the changes of fatty acids composition under biotic and abiotic stress conditions are mostly unexplored. Scientists are still looking for new species with naturally high content of AA and EPA. Efforts have been made to enhance the production of AA and EPA in bryophytes in the past few decades, either by exposing them to different environmental stressors or by transgenic approaches.

\subsection{Developmental Stages}

Different developmental stages of bryophytes have different fatty acid composition. Protonema was richer in AA but less in EPA compare to gametophytes in five moss species (Table 3), but a reverse result was concluded in P. patens [13]. However, further studies are needed to understand the changes better.

\subsection{Environmental Stressors}

Environmental factors are keys to enhance PUFA production. PUFAs content and the $\omega-3 / \omega-6$ ratio are affected by many factors such as temperature, light, $\mathrm{pH}$ and nutrition [65,66]. Fatty acids compositions of several mosses and liverworts have been examined under different environmental conditions. When cultivated in cell cultures, the size of inoculum and ferrous ion also affect PUFA productivity [64].

Light is one of the most important factors that affects the accumulation of PUFAs, not only the light intensity but also the light quality [65]. Blue light enhances the accumulation of EPA content in M. polymorpha but has little effect on AA content. In M. polymorpha cell cultures the optimum light intensity has been found to be 80 photons $\mu \mathrm{mol} / \mathrm{m}^{2} / \mathrm{s}$ [65].

After cold treatments in the cell cultures of the moss Rhytidiadelphus squarrosus, Eurhynchium striatum [59] and the liverwort M. polymorpha [88], all of them showed increase of $\omega-3$ PUFAs (EPA) and decrease of $\omega-6$ PUFAs (AA) although growth deficits were also observed. The low temperature resulted in an increase of EPA; more specifically, EPA content at $5{ }^{\circ} \mathrm{C}$ was three times higher than at $25^{\circ} \mathrm{C}$ in $M$. polymorpha, indicating $\omega-3$ desaturase gene expression was induced at cold temperatures [88]. During cold stress of M. polymorpha a change in EPA was found for monogalactosyldiacylglycerol (MGDG) and chloroplastic phosphatidycholine (PC) [63]. Overall temperature regulation can assist in the production of high levels of PUFAs and can be regulated so that the overall growth rate is not affected.

Nutrients such as nitrogen, sulfur, phosphor and minerals are essential for a healthy bryophyte culture. Both total lipid contents and PUFAs proportion of four moss species Ctenidium molluscum, Pogonatum urnigerum, Dichodontium pellucidum and Tortella tortuosa showed a decrease in levels when the $\mathrm{NO}_{3}{ }^{-}$concentration was increased in the media (Table 4), indicating that mosses synthesize more proteins rather than lipids when the medium is rich in nitrogen [89]. Thus, in order to obtain 
moss biomass with high PUFA content, it was suggested to use biphasic process as growing moss on nitrogen-rich medium for high biomass concentration, followed by a nitrogen starvation phase for improving the lipid content. With modern bioreactor technologies this could be linked with temperature control, which will allow the bryophyte to grow fast, and when the nitrogen is used then the temperature can be lowered to induce PUFA production.

Table 4. Environmental factors affecting AA and EPA content in bryophytes, as well as genetic modification that result in high AA and EPA content.

\begin{tabular}{|c|c|c|c|c|c|c|c|}
\hline \multicolumn{8}{|c|}{ Environmental Stresses } \\
\hline Species & $\begin{array}{l}\text { Growtd } \\
\text { Conditions }\end{array}$ & $\begin{array}{l}\text { Environmental } \\
\text { Factors }\end{array}$ & Variables & $\begin{array}{c}\text { Biomass } \\
\text { Growtd } \\
\text { (mg/plant) }\end{array}$ & AA * & EPA * & References \\
\hline \multirow{6}{*}{$\begin{array}{l}\text { Rhytidiadelphus } \\
\text { squarrosus }\end{array}$} & \multirow{6}{*}{ MS medium } & \multirow{6}{*}{ Temperature } & $5^{\circ} \mathrm{C}$ & & 18.6 & 9.4 & \multirow{14}{*}{ [59] } \\
\hline & & & $10^{\circ} \mathrm{C}$ & & 23.8 & 13.7 & \\
\hline & & & $15^{\circ} \mathrm{C}$ & & 24.6 & 11.7 & \\
\hline & & & $20^{\circ} \mathrm{C}$ & & 32.7 & 5.7 & \\
\hline & & & $25^{\circ} \mathrm{C}$ & & 26.8 & 6.3 & \\
\hline & & & $30^{\circ} \mathrm{C}$ & & 23.0 & 2.4 & \\
\hline \multirow{6}{*}{$\begin{array}{l}\text { Eurhynchium } \\
\text { striatum }\end{array}$} & \multirow{6}{*}{ MS medium } & \multirow{6}{*}{ Temperature } & $5^{\circ} \mathrm{C}$ & & 28.4 & 5.6 & \\
\hline & & & $10^{\circ} \mathrm{C}$ & & 32.5 & 4.9 & \\
\hline & & & $15^{\circ} \mathrm{C}$ & & 30.5 & 7.5 & \\
\hline & & & $20^{\circ} \mathrm{C}$ & & 34.1 & 2.9 & \\
\hline & & & $25^{\circ} \mathrm{C}$ & & 32.9 & 3.0 & \\
\hline & & & $30^{\circ} \mathrm{C}$ & & 31.7 & 2.4 & \\
\hline \multirow{2}{*}{$\begin{array}{l}\text { Rhytidiadelphus } \\
\text { squarrosus }\end{array}$} & \multirow{2}{*}{ MS medium } & \multirow{2}{*}{$\mathrm{pH}$} & 5.8 & & 13.2 & & \\
\hline & & & 6.5 & & 9.5 & & \\
\hline \multirow{2}{*}{$\begin{array}{l}\text { Marchantia } \\
\text { polymorpha }\end{array}$} & \multirow{2}{*}{ MS medium } & \multirow{2}{*}{ Temperature } & $15^{\circ} \mathrm{C}$ & & 12.1 & 3.6 & \multirow{2}{*}{ [63] } \\
\hline & & & $25^{\circ} \mathrm{C}$ & & 11 & 3 & \\
\hline \multirow{2}{*}{$\begin{array}{l}\text { Marchantia } \\
\text { polymorpha }\end{array}$} & \multirow{2}{*}{$\begin{array}{l}\text { M51C solid } \\
\text { medium }\end{array}$} & \multirow{2}{*}{ Temperature } & $5^{\circ} \mathrm{C}$ & & 2 & 14 & \multirow{2}{*}{ [88] } \\
\hline & & & $25^{\circ} \mathrm{C}$ & & 3.5 & 5 & \\
\hline \multirow{3}{*}{$\begin{array}{l}\text { Ctenidium } \\
\text { molluscum }\end{array}$} & & \multirow{12}{*}{ Nitrogen (g/L) } & 0 & & 22.9 & 5.3 & \multirow{12}{*}{ [89] } \\
\hline & & & 0.04 & & 14.7 & 2.6 & \\
\hline & & & 0.4 & & 17.5 & 5.0 & \\
\hline \multirow{3}{*}{$\begin{array}{l}\text { Pogonatum } \\
\text { urnigerum }\end{array}$} & & & 0 & & 2.8 & 0.4 & \\
\hline & & & 0.04 & & 3.0 & 3.9 & \\
\hline & & & 0.4 & & 1.7 & 1.1 & \\
\hline \multirow{3}{*}{$\begin{array}{l}\text { Dichodontium } \\
\text { pellucidum }\end{array}$} & & & 0 & & 1.7 & 1.1 & \\
\hline & & & 0.04 & & 3.4 & 2.2 & \\
\hline & & & 0.4 & & 3.3 & 1.9 & \\
\hline \multirow{3}{*}{ Tortella tortuosa } & & & 0 & & 5.1 & 1.8 & \\
\hline & & & 0.04 & & 5.3 & 1.5 & \\
\hline & & & 0.4 & & 5.8 & 1.9 & \\
\hline
\end{tabular}


Table 4. Environmental factors affecting AA and EPA content in bryophytes, as well as genetic modification that result in high AA and EPA content.

\begin{tabular}{|c|c|c|c|c|c|c|c|}
\hline \multicolumn{8}{|c|}{ Environmental Stresses } \\
\hline Species & $\begin{array}{l}\text { Growtd } \\
\text { Conditions }\end{array}$ & $\begin{array}{l}\text { Environmental } \\
\text { Factors }\end{array}$ & Variables & $\begin{array}{l}\text { Biomass } \\
\text { Growtd } \\
\text { (mg/plant) }\end{array}$ & AA * & EPA * & References \\
\hline \multirow{7}{*}{$\begin{array}{l}\text { Marchantia } \\
\text { polymorpha }\end{array}$} & & \multirow{4}{*}{$\begin{array}{l}\text { Photon flux } \\
\text { density } \\
\left(\mathrm{umol} / \mathrm{m}^{2} / \mathrm{s}\right)\end{array}$} & 3 & $1028.2^{+}$ & $2.8^{+}$ & $2.6^{+}$ & \multirow{7}{*}{ [64] } \\
\hline & & & 9 & $979.0^{+}$ & $2.9^{+}$ & $2.8^{+}$ & \\
\hline & & & 20 & $976.8^{+}$ & $3.7^{+}$ & $3.4^{+}$ & \\
\hline & & & 32 & $987.0^{+}$ & $3.3^{+}$ & $3.1^{+}$ & \\
\hline & & \multirow{3}{*}{$\begin{array}{l}\text { Osmolarity } \\
(\mathrm{NaCl} \%)\end{array}$} & 0 & $576.5^{+}$ & \multicolumn{2}{|c|}{$3.0^{+}\left(\mathrm{C}_{20}\right.$ PUFA $)$} & \\
\hline & & & 0.2 & $651.6^{+}$ & \multicolumn{2}{|c|}{$3.0+\left(C_{20}\right.$ PUFA $)$} & \\
\hline & & & 0.5 & $62.9^{+}$ & \multicolumn{2}{|c|}{$0.2+\left(C_{20}\right.$ PUFA $)$} & \\
\hline \multirow{5}{*}{$\begin{array}{l}\text { Marchantia } \\
\text { polymorpha }\end{array}$} & & \multirow{2}{*}{ Light quality } & White & 543 & \multicolumn{2}{|c|}{ Not reported } & \multirow{5}{*}{ [65] } \\
\hline & & & Blue & 454 & $\begin{array}{l}\text { Varied } \\
\text { slightly }\end{array}$ & $\begin{array}{l}\text { 1.5-fold higher } \\
\text { than under } \\
\text { white light }\end{array}$ & \\
\hline & & \multirow{3}{*}{$\begin{array}{l}\text { Light intensity } \\
\left(\mathrm{umol} / \mathrm{m}^{2} / \mathrm{s}\right)\end{array}$} & 40 & 696 & 5.7 & 2.5 & \\
\hline & & & 60 & 1075 & 5.7 & 3.0 & \\
\hline & & & 80 & 1088 & 5.7 & 4.5 & \\
\hline \multicolumn{8}{|c|}{ Genetic Transformation } \\
\hline Species & \multicolumn{2}{|c|}{ Types } & \multicolumn{2}{|c|}{ AA * } & \multicolumn{2}{|c|}{ EPA * } & Reference \\
\hline \multirow{3}{*}{$\begin{array}{l}\text { Marchantia } \\
\text { polymorpha }\end{array}$} & \multicolumn{2}{|c|}{ WT } & \multicolumn{2}{|c|}{3.1} & \multicolumn{2}{|r|}{5.9} & \\
\hline & \multicolumn{2}{|c|}{ DEOE-34 } & \multicolumn{2}{|c|}{5.0} & \multicolumn{2}{|c|}{12.1} & [40] \\
\hline & \multicolumn{2}{|c|}{ DEDOE-58 } & \multicolumn{2}{|c|}{11.4} & \multicolumn{2}{|r|}{8.9} & \\
\hline
\end{tabular}

MS: Murashige-Skoog medium; WT, wild type; DEOE-34, overexpression of $\Delta-6$ desaturase and $\Delta-6$ elongase; DEDOE-58, overexpression of $\Delta-5$ desaturase, $\Delta-6$ desaurase and $\Delta-6$ elongase. ${ }^{*} \%$ of total lipids; ${ }^{+} \mathrm{mg} / \mathrm{L} / \mathrm{Day}$.

\subsection{Genetic Transformation}

All studies of genetic transformation to enhance vl-PUFA production in bryophytes have been focused on M. polymorpha [40] and P. patens [90,91]. Overexpression of genes encoding enzymes $\Delta-5$ desaturase, $\Delta-6$ desaturase and $\Delta-6$ elongase in M. polymorpha resulted in 3- and 2-fold increase of AA and EPA, respectively, compared to those in the wild type [40]. When both $\Delta-6$ elongase from P. patens and lipid-linked $\Delta-5$ desaturase from diatom Phaeodactylum tricornutum were expressed in marine alga Saccharomyces cerevisiae, high proportions of AA and EPA were detected because almost all $\Delta-6$ desaturated products were elongated [92].

\section{Future Perspectives}

Bryophytes are underexploited for their valuable biologically-active compounds. High contents of arachidonic acid and eicosapentenoic acid in bryophytes highlight their potential usage in the pharmaceutical industry, food industry and cosmetics. Efforts have been put on in vitro cultivation of bryophytes in liquid culture in bioreactors in order to obtain both sufficient biomass and high contents of valuable fatty acids. Current studies in the large scale tend to focus on model species the P. patens. The techniques of the in vitro cultivation of P. Patens can be transferred to other attractive species to meet industrial demands. Lipidomics is a powerful tool to examine lipid-related molecular mechanisms and lipid biomarkers in bryophytes in response to stress conditions.

Author Contributions: Writing—original draft preparation, Y.L.; writing—review and editing, F.F.E., M.T. and H.T.S.; All authors approved the final manuscript.

Funding: This study is funded by Marie Sklodowska-Curie Actions, Innovative Training Networks under European Union Horizon 2020 programme under grant agreement No. 765115-MossTech. 
Conflicts of Interest: The authors declare no conflict of interest.

\section{Abbreviations}

AA

ACPs

AFAs

ALA

APCI

DGLA

EPA

ER

ESI-MS/MS

ETA

FAs

GC-FID

GC-MS

GL

GLA

HPLC

LA

LC-MS

MALDI-TOF-MS

MGDG

MUFAs

NL

NMR

$\mathrm{OA}$

PC

PL

PUFAs

SA

SDA

SFAs

SPE

TAGs

TL

TLC

vl-PUFAs arachidonic acid

acyl carrier proteins

acetylenic fatty acids

$\alpha$-linolenic acid

atmospheric pressure chemical ionization

di-homo $\gamma$-linolenic acid

eicosapentaenoic acid

endoplasmic reticulum

electrospray ionization triple quadrupole mass spectrometry

eicosatetraenoic acid

fatty acids

gas chromatography-flame ionization detector

gas chromatography-mass spectrometry

glycolipid

$\gamma$-linolenic acid

high-performance liquid chromatography

linoleic acid

liquid chromatography-mass spectrometry

matrix-assisted laser desorption/ionization time-of-flight mass spectrometry

monogalactosyldiacylglycerol

monounsaturated fatty acids

neutral lipid

nuclear magnetic resonance

oleic acid

phosphatidycholine

polar lipid

polyunsaturated fatty acids

stearic acid

stearidonic acid

saturated fatty acids

solid phase extraction

triacylglycerides

total lipid

thin layer chromatography

very long chain polyunsaturated fatty acids

\section{References}

1. Asakawa, Y.; Ludwiczuk, A.; Nagashima, F. Chemical Constituents of Bryophytes; Progress in the Chemistry of Organic Natural Products; Springer: Vienna, Austria, 2013; Volume 95, ISBN 978-3-7091-1083-6.

2. Australian National Botanic Gardens Habitats-Ecology-Bryophytes. Available online: https://www.anbg.gov. au/bryophyte/ecology-habitats.html (accessed on 23 October 2018).

3. Qiu, Y.-L.; Palmer, J.D. Phylogeny of early land plants: Insights from genes and genomes. Trends Plant Sci. 1999, 4, 26-30. [CrossRef]

4. Sheffield, L.; Rowntree, J. Bryophyte Biology, 2nd ed.; Cambridge University Press: Cambridge, UK, 2009; Volume 104.

5. Vesty, E.F.; Saidi, Y.; Moody, L.A.; Holloway, D.; Whitbread, A.; Needs, S.; Choudhary, A.; Burns, B.; McLeod, D.; Bradshaw, S.J.; et al. The decision to germinate is regulated by divergent molecular networks in spores and seeds. New Phytol. 2016, 211, 952-966. [CrossRef]

6. He, X.; Sun, Y.; Zhu, R.L.R.-L. The Oil Bodies of Liverworts: Unique and Important Organelles in Land Plants. CRC Crit. Rev. Plant Sci. 2013, 32, 293-302. [CrossRef] 
7. Klavina, L. Composition of Mosses, Their Metabolites and Environmental Stress Impacts. Ph.D. Thesis, University of Latvia, Riga, Latvia, 2018.

8. Roberts, A.W.; Roberts, E.M.; Haigler, C.H. Moss cell walls: Structure and biosynthesis. Front. Plant Sci. 2012, 3, 166. [CrossRef]

9. Haines, W.P.; Renwick, J.A.A. Bryophytes as food: Comparative consumption and utilization of mosses by a generalist insect herbivore. Entomol. Exp. Appl. 2009, 133, 296-306. [CrossRef]

10. Sabovljević, M.S.; Sabovljević, A.D.; Ikram, N.K.K.; Peramuna, A.; Bae, H.; Simonsen, H.T. Bryophytes-An emerging source for herbal remedies and chemical production. Plant Genet. Resour. 2016, 14, 314-327. [CrossRef]

11. Reski, R. Quantitative moss cell biology. Curr. Opin. Plant Biol. 2018, 46, 39-47. [CrossRef] [PubMed]

12. Klavina, L.; Bikovens, O.; Steinberga, I.; Maksimova, V.; Eglīte, L. Characterization of chemical composition of some bryophytes common in Latvia. Environ. Exp. Biol. 2012, 10, 27-34.

13. Beike, A.K.; Jaeger, C.; Zink, F.; Decker, E.L.; Reski, R. High contents of very long-chain polyunsaturated fatty acids in different moss species. Plant Cell Rep. 2014, 33, 245-254. [CrossRef]

14. Shinmen, Y.; Katoh, K.; Shimizu, S.; Jareonkitmongkol, S.; Yamada, H. Production of arachidonic acid and eicosapentaenoic acids by Marchantia polymorpha in cell culture. Phytochemistry 1991, 30, 3255-3260. [CrossRef]

15. Baas, M.; Pancost, R.; van Geel, B.; Sinninghe Damsté, J.S. A comparative study of lipids in Sphagnum species. Org. Geochem. 2000, 31, 535-541. [CrossRef]

16. Tosun, A.; Nagashima, F.; Asakawa, Y. Terpenoid and Steroid Components of Selected Liverworts. Chem. Nat. Compd. 2015, 51, 387-391. [CrossRef]

17. Figueiredo, A.C.; Sim-Sim, M.; Costa, M.M.; Barroso, J.G.; Pedro, L.G.; Esquível, M.G.; Gutierres, F.; Lobo, C.; Fontinha, S. Comparison of the essential oil composition of four Plagiochila species: P. bifaria, P. maderensis, $P$. retrorsa and P. stricta. Flavour Fragr. J. 2005, 20, 703-709. [CrossRef]

18. Klavina, L.; Springe, G.; Nikolajeva, V.; Martsinkevich, I.; Nakurte, I.; Dzabijeva, D.; Steinberga, I. Chemical Composition Analysis, Antimicrobial Activity and Cytotoxicity Screening of Moss Extracts (Moss Phytochemistry). Molecules 2015, 20, 17221-17243. [CrossRef]

19. Asakawa, Y.; Ludwiczuk, A. Bryophytes: Liverworts, Mosses, and Hornworts: Extraction and Isolation Procedures. In Metabolomics Tools for Natural Product Discovery: Methods and Protocols; Roessner, U., Dias, D.A., Eds.; Humana Press: Totowa, NJ, USA, 2013; pp. 1-20. ISBN 978-1-62703-577-4.

20. Duckett, J.G.; Burch, J.; Fletcher, P.W.; Matcham, H.W.; Read, D.J.; Russell, A.J.; Pressel, S. In vitro cultivation of bryophytes: A review of practicalities, problems, progress and promise. J. Bryol. 2004, 26, 3-20.

21. Hohe, A.; Reski, R. From axenic spore germination to molecular farming. Plant Cell Rep. 2005, $23,513-521$. [CrossRef]

22. Christie, W.W.; Han, X. Lipids: Their structures and occurrence. In Lipid Analysis; Elsevier: Amsterdam, The Netherlands, 2012; pp. 3-19. ISBN 978-0-9552512-4-5.

23. Dembitsky, V.M. Lipids of bryophytes. Prog. Lipid Res. 1993, 32, 281-356. [CrossRef]

24. Harris, E.S.J. Ethnobryology: Traditional uses and folk classification of bryophytes. Bryologist 2008, 111, 169-217. [CrossRef]

25. Chandra, S.; Chandra, D.; Barh, A.; Pankaj; Pandey, R.K.; Sharma, I.P. Bryophytes: Hoard of remedies, an ethno-medicinal review. J. Tradit. Complement. Med. 2017, 7, 94-98. [CrossRef]

26. Glime, J.M. Volume 5, Chapter 2-1: Medical Uses: Medical Conditions. Available online: http: //digitalcommons.mtu.edu/bryophyte-ecology/ (accessed on 12 October 2018).

27. Büttner-Mainik, A.; Parsons, J.; Jérôme, H.; Hartmann, A.; Lamer, S.; Schaaf, A.; Schlosser, A.; Zipfel, P.F.; Reski, R.; Decker, E.L. Production of biologically active recombinant human factor $\mathrm{H}$ in Physcomitrella. Plant Biotechnol. J. 2011, 9, 373-383. [CrossRef]

28. Reski, R.; Parsons, J.; Decker, E.L. Moss-made pharmaceuticals: From bench to bedside. Plant Biotechnol. J. 2015, 13, 1191-1198. [CrossRef] [PubMed]

29. Frahm, J.P.; Kirchhoff, K. Antifeeding effects of bryophyte extracts from Neckera crispa and Porella obtusata against the slug Arion lusitanicus. Cryptogam. Bryol. 2002, 23, 271-275.

30. Frahm, J.-P.P. Recent Developments of Commercial Products from Bryophytes. Bryologist 2004, 107, $277-283$. [CrossRef] 
31. Asakawa, Y. Bryophytes: Chemical diversity, synthesis and biotechnology. A review. Flavour Fragr. J. 2011, 26, 318-320. [CrossRef]

32. Asakawa, Y.; Ludwiczuk, A.; Nagashima, F. Phytochemical and biological studies of bryophytes. Phytochemistry 2013, 91, 52-80. [CrossRef] [PubMed]

33. Chen, F.; Ludwiczuk, A.; Wei, G.; Chen, X.; Crandall-Stotler, B.; Bowman, J.L. Terpenoid Secondary Metabolites in Bryophytes: Chemical Diversity, Biosynthesis and Biological Functions. CRC Crit. Rev. Plant Sci. 2018, 37, 210-231. [CrossRef]

34. Calder, P.C.; Yaqoob, P. Omega-3 polyunsaturated fatty acids and human health outcomes. BioFactors 2009, 35, 266-272. [CrossRef]

35. Bhardwaj, K.; Verma, N.; Trivedi, R.K.; Bhardwaj, S.; Shukla, N. Significance of Ratio of Omega-3 and Omega-6 in Human Health with Special Reference to Flaxseed Oil. Int. J. Biol. Chem. 2016, 10, 1-6. [CrossRef]

36. Resemann, H.C.; Lewandowska, M.; Gömann, J.; Feussner, I. Membrane Lipids, Waxes and Oxylipins in the Moss Model Organism Physcomitrella patens. Plant Cell Physiol. 2019, 60, 1166-1175. [CrossRef]

37. Jiao, J.; Zhang, Y. Transgenic Biosynthesis of Polyunsaturated Fatty Acids: A Sustainable Biochemical Engineering Approach for Making Essential Fatty Acids in Plants and Animals. Chem. Rev. 2013, 113, 3799-3814. [CrossRef]

38. Rensing, S.A.; Lang, D.; Zimmer, A.D.; Terry, A.; Salamov, A.; Shapiro, H.; Nishiyama, T.; Perroud, P.-F.; Lindquist, E.A.; Kamisugi, Y.; et al. The Physcomitrella Genome Reveals Evolutionary Insights into the Conquest of Land by Plants. Science 2008, 319, 64-69. [CrossRef] [PubMed]

39. Bowman, J.L.; Kohchi, T.; Yamato, K.T.; Jenkins, J.; Shu, S.; Ishizaki, K.; Yamaoka, S.; Nishihama, R.; Nakamura, Y.; Berger, F.; et al. Insights into Land Plant Evolution Garnered from the Marchantia polymorpha Genome. Cell 2017, 171, 287-304.e15. [CrossRef] [PubMed]

40. Kajikawa, M.; Matsui, K.; Ochiai, M.; Tanaka, Y.; Kita, Y.; Ishimoto, M.; Kohzu, Y.; Shoji, S.; Yamato, K.T.; Ohyama, K.; et al. Production of Arachidonic and Eicosapentaenoic Acids in Plants Using Bryophyte Fatty Acid $\Delta 6$-Desaturase, $\Delta 6$-Elongase, and $\Delta 5$-Desaturase Genes. Biosci. Biotechnol. Biochem. 2008, 72, 435-444. [CrossRef] [PubMed]

41. Řezanka, T.; Sigler, K. Odd-numbered very-long-chain fatty acids from the microbial, animal and plant kingdoms. Prog. Lipid Res. 2009, 48, 206-238. [CrossRef] [PubMed]

42. Kim, H.Y.; Salem, N. Separation of lipid classes by solid phase extraction. J. Lipid Res. 1990, 31, $2285-2289$.

43. Klavina, L.; Kviesis, J. Solid Phase Extraction of Bryophyte Lipids. Mater. Sci. Appl. Chem. 2015, 32, 58-67.

44. Yang, K.; Zhao, Z.; Gross, R.W.; Han, X. Identification and Quantitation of Unsaturated Fatty Acid Isomers by Electrospray Ionization Tandem Mass Spectrometry: A Shotgun Lipidomics Approach. Anal. Chem. 2011, 83, 4243-4250. [CrossRef]

45. Ahlstrand, N.I.; Reghev, N.H.; Markussen, B.; Hansen, H.C.B.; Eiriksson, F.F.; Thorsteinsdóttir, M.; Rønsted, N.; Barnes, C.J. Untargeted metabolic profiling reveals geography as the strongest predictor of metabolic phenotypes of a cosmopolitan weed. Ecol. Evol. 2018, 8, 6812-6826. [CrossRef]

46. Welti, R.; Li, W.; Li, M.; Sang, Y.; Biesiada, H.; Zhou, H.-E.; Rajashekar, C.B.; Williams, T.D.; Wang, X. Profiling Membrane Lipids in Plant Stress Responses. J. Biol. Chem. 2002, 277, 31994-32002. [CrossRef]

47. Qin, L.; Zhang, Y.; Liu, Y.; He, H.; Han, M.; Li, Y.; Zeng, M.; Wang, X. Recent advances in matrix-assisted laser desorption/ionisation mass spectrometry imaging (MALDI-MSI) for in situ analysis of endogenous molecules in plants. Phytochem. Anal. 2018, 29, 351-364. [CrossRef]

48. Podolskaya, E.P.; Gladchuk, A.S.; Keltsieva, O.A.; Dubakova, P.S.; Silyavka, E.S.; Lukasheva, E.; Zhukov, V.; Lapina, N.; Makhmadalieva, M.R.; Gzgzyan, A.M.; et al. Thin Film Chemical Deposition Techniques as a Tool for Fingerprinting of Free Fatty Acids by Matrix-Assisted Laser Desorption/Ionization Time-of-Flight Mass Spectrometry. Anal. Chem. 2019, 91, 1636-1643. [CrossRef] [PubMed]

49. Okazaki, Y.; Kamide, Y.; Hirai, M.Y.Y.; Saito, K. Plant lipidomics based on hydrophilic interaction chromatography coupled to ion trap time-of-flight mass spectrometry. Metabolomics 2013, 9, 121-131. [CrossRef] [PubMed]

50. Lu, N.; Wei, D.; Chen, F.; Yang, S.-T.T. Lipidomic profiling and discovery of lipid biomarkers in snow alga Chlamydomonas nivalis under salt stress. Eur. J. Lipid Sci. Technol. 2012, 114, 253-265. [CrossRef]

51. Bromke, M.A.; Sabir, J.S.; Alfassi, F.A.; Hajarah, N.H.; Kabli, S.A.; Al-Malki, A.L.; Ashworth, M.P.; Méret, M.; Jansen, R.K.; Willmitzer, L. Metabolomic Profiling of 13 Diatom Cultures and Their Adaptation to Nitrate-Limited Growth Conditions. PLoS ONE 2015, 10, e0138965. [CrossRef] 
52. Zhang, P.; Wang, X.; Wang, T.; Zhu, P.; Yang, L. The major changes in lipid composition of Sargassum horneri during different growth phases. J. Appl. Phycol. 2018, 30, 517-523. [CrossRef]

53. Anderson, W.H.; Gellerman, J.L.; Schlenk, H. Arachidonic and eicosapentaenoic acids in developing gametophores and sporophytes of the moss, Mnium cuspidatum. Lipids 1972, 7, 710-714. [CrossRef]

54. Åndersson, B.; Anderson, W.H.; Chipault, J.R.; Ellison, E.C.; Fenton, S.W.; Gellerman, J.L.; Hawkins, J.M.; Schlenk, H. 9,12,15-octadecatrien-6-ynoic acid, new acetylenic acid from mosses. Lipids 1974, 9, 506-511. [CrossRef]

55. Kohn, G.; Demmerle, S.S.; Vandekerkhove, O.; Hartmann, E.; Beutelmann, P.; Vandekerkhove, C.; Hartmann, E.; Beutelmann, P.; Vandekerkhove, O.; Hartmann, E.; et al. Distribution and chemotaxonomic significance of acetylenic fatty acids in mosses of the dicranales. Phytochemistry 1987, 26, 2271-2275. [CrossRef]

56. Vierengel, A.; Kohn, G.; Vandekerkhove, O.; Hartmann, E. 9-octadecen-6-ynoic acid from Riccia fluitans. Phytochemistry 1987, 26, 2101-2102. [CrossRef]

57. Kohn, G.; Vandekerkhove, O.; Hartmann, E.; Beutelmann, P. Acetylenic fatty acids in the ricciaceae (hepaticae). Phytochemistry 1988, 27, 1049-1051. [CrossRef]

58. Hansen, C.E.; Rossi, P. Arachidonic and eicosapentaenoic acids in brachytheciaceae and hypnaceae moss species. Phytochemistry 1990, 29, 3749-3754. [CrossRef]

59. Hansen, C.E.; Rossi, P. Effects of culture conditions on accumulation of arachidonic and eicosapentaenoic acids in cultured cells of Rhytidiadelphus squarrosus and Eurhynchium striatum. Phytochemistry 1991, 30, 1837-1841. [CrossRef]

60. Sewón, P. Fatty acyl composition of monogalactosyldiacyl glycerols in Bryophyta. Phytochemistry 1992, 31, 3461-3465. [CrossRef]

61. Dembitsky, V.M.; Rezanka, T.; Bychek, I.A.; Afonina, O.M. Polar lipid and fatty acid composition of some bryophytes. Phytochemistry 1993, 33, 1009-1014. [CrossRef]

62. Dembitsky, V.M.; Rezanka, T. Distribution of diacylglycerylhomoserines, phospholipids and fatty acids in thirteen moss species from Southwestern Siberia. Biochem. Syst. Ecol. 1995, 23, 71-78. [CrossRef]

63. Saruwatari, M.; Takio, S.; Ono, K. Low temperature-induced accumulation of eicosapentaenoic acids in Marchantia polymorpha cells. Phytochemistry 1999, 52, 367-372. [CrossRef]

64. Chiou, S.-Y.; Su, W.-W.; Su, Y.-C. Optimizing production of polyunsaturated fatty acids in Marchantia polymorpha cell suspension culture. J. Biotechnol. 2001, 85, 247-257. [CrossRef]

65. Takemura, M.; Okimura, Y.; Kida, H.; Hamada, T.; Ohyama, K. Blue light enhances the accumulation of eicosapentaenoic acid in a liverwort, Marchantia polymorpha L. Plant Biotechnol. 2011, 28, 489-492. [CrossRef]

66. Chodok, P.; Kanjana-Opas, A.; Kaewsuwan, S. The Plackett-Burman Design for Evaluating the Production of Polyunsaturated Fatty Acids by Physcomitrella patens. J. Am. Oil Chem. Soc. 2010, 87, 521-529. [CrossRef]

67. You, J.; Zhao, X.; Suo, Y.; Li, Y.; Wang, H.; Chen, G. Determination of long-chain fatty acids in bryophyte plants extracts by HPLC with fluorescence detection and identification with MS. J. Chromatogr. B 2007, 848, 283-291. [CrossRef]

68. Pejin, B.; Bianco, A.; Newmaster, S.; Sabovljević, M.; Vujisić, L.; Tešević, V.; Vajs, V.; De Rosa, S. Fatty acids of Rhodobryum ontariense (Bryaceae). Nat. Prod. Res. 2012, 26, 696-702. [CrossRef] [PubMed]

69. Pejin, B.; Vujisić, L.; Sabovljević, M.; Tešević, V.; Vajs, V. Fatty acid chemistry of Atrichum undulatum and Hypnum andoi. Hem. Ind. 2012, 66, 207-209. [CrossRef]

70. Mitra, S. High Content of Dicranin in Anisothecium spirale (Mitt.) Broth., a Moss from Eastern Himalayas and Its Chemotaxonomic Significance. Lipids 2017, 52, 173-178. [CrossRef] [PubMed]

71. Hildebrand, D. Production of Unusual Fatty Acids in Plants. Available online: http://lipidlibrary.aocs.org/ Biochemistry/content.cfm?ItemNumber=40317 (accessed on 12 March 2019).

72. Prins, H.H.T. Why Are Mosses Eaten in Cold Environments Only? Oikos 1982, 38, 374. [CrossRef]

73. Glime, J.M. Volume 1, Chapter 10-2: Temperature: Cold. Available online: http://digitalcommons.mtu.edu/ bryophyte-ecology/ (accessed on 13 November 2018).

74. Chen, Y.; Meesapyodsuk, D.; Qiu, X. Transgenic production of omega-3 very long chain polyunsaturated fatty acids in plants: Accomplishment and challenge. Biocatal. Agric. Biotechnol. 2014, 3, 38-43. [CrossRef]

75. Dembitsky, V.M.; Rezanka, T. Acetylenic fatty acids of the dicranaceae. Phytochemistry 1994, 36, 685-689. [CrossRef] 
76. Dembitsky, V.M.; Rezanka, T.; Bychek, I.A.; Afonina, O.M. Acetylenic acids and lipid compositions of some mosses from Russia. Phytochemistry 1993, 33, 1021-1027. [CrossRef]

77. Croisier, E.; Rempt, M.; Pohnert, G. Survey of volatile oxylipins and their biosynthetic precursors in bryophytes. Phytochemistry 2010, 71, 574-580. [CrossRef]

78. Pejin, B.; Vujisić, L.; Sabovljević, M.; Tešević, V.; Vajs, V.; Vujisic, L.; Sabovljevic, M.; Tesevic, V.; Vajs, V. The moss Mnium hornum, a promising source of arachidonic acid. Chem. Nat. Compd. 2012, 48, 120-121. [CrossRef]

79. Pejin, B.; Vujisic, L.; Sabovljevic, A.; Sabovljevic, M.; Tesevic, V.; Vajs, V. Fatty acids of some moss species from Germany. Asian J. Chem. 2011, 23, 5187-5188.

80. Koskimies, K.; Simola, L.K. The fatty acid composition of some Sphagnum species. Can. J. Bot. 1980, 58, 259-263. [CrossRef]

81. Dembitsky, V.M.; Rezanka, T. Distribution of acetylenic acids and polar lipids in some aquatic bryophytes. Phytochemistry 1995, 40, 93-97. [CrossRef]

82. Shanab, S.M.M.; Hafez, R.M.; Fouad, A.S. A review on algae and plants as potential source of arachidonic acid. J. Adv. Res. 2018, 11,3-13. [CrossRef] [PubMed]

83. Kihara, H.; Tanaka, M.; Yamato, K.T.; Horibata, A.; Yamada, A.; Kita, S.; Ishizaki, K.; Kajikawa, M.; Fukuzawa, H.; Kohchi, T.; et al. Arachidonic acid-dependent carbon-eight volatile synthesis from wounded liverwort (Marchantia polymorpha). Phytochemistry 2014, 107, 42-49. [CrossRef] [PubMed]

84. Hartmann, E.; Beutelmann, P.; Vandekerkhove, O.; Euler, R.; Kohn, G. Moss cell cultures as sources of arachidonic and eicosapentaenoic acids. FEBS Lett. 1986, 198, 51-55. [CrossRef]

85. Gellerman, J.L.; Anderson, W.H.; Richardson, D.G.; Schlenk, H. Distribution of arachidonic and eicosapentaenoic acids in the lipids of mosses. Biochim. Biophys. Acta Lipids Lipid Metab. 1975, 388, 277-290. [CrossRef]

86. Pejin, B.; Vujisić, L.; Sabovljević, A.; Sabovljević, M.; Tešević, V.; Vajs, V. An insight into fatty acid chemistry of Rhytididelphus squarrosus (Hedw.) Warnst. Bot. Serbia 2011, 35, 99-101.

87. Abbadi, A.; Domergue, F.; Bauer, J.; Napier, J.A.; Welti, R.; Zähringer, U.; Cirpus, P.; Heinz, E. Biosynthesis of Very-Long-Chain Polyunsaturated Fatty Acids in Transgenic Oilseeds: Constraints on Their Accumulation. Plant Cell 2004, 16, 2734-2748. [CrossRef]

88. Takemura, M.; Hamada, T.; Kida, H.; Ohyma, K. Cold-Induced Accumulation of $\omega-3$ Polyunsaturated Fatty Acid in a Liverwort, Marchantia polymorpha L. Biosci. Biotechnol. Biochem. 2012, 76, 785-790. [CrossRef]

89. Al-Hasan, R.H.; Ka'wash, H.H.; Radwan, S.S. Enrichment of Mosses with Lipids and Polyunsaturated Fatty Acids by Nitrogen Starvation. Bryologist 1991, 94, 196. [CrossRef]

90. Kaewsuwan, S.; Bunyapraphatsara, N.; Cove, D.J.; Quatrano, R.S.; Chodok, P. High level production of adrenic acid in Physcomitrella patens using the algae Pavlova sp. $\Delta 5$-elongase gene. Bioresour. Technol. 2010, 101, 4081-4088. [CrossRef] [PubMed]

91. Zank, T.K.; Zähringer, U.; Beckmann, C.; Pohnert, G.; Boland, W.; Holtorf, H.; Reski, R.; Lerchl, J.; Heinz, E. Cloning and functional characterisation of an enzyme involved in the elongation of $\Delta 6$-polyunsaturated fatty acids from the moss Physcomitrella patens. Plant J. 2002, 31, 255-268. [CrossRef] [PubMed]

92. Domergue, F.; Abbadi, A.; Zähringer, U.; Moreau, H.; Heinz, E. In vivo characterization of the first acyl-CoA $\Delta 6$-desaturase from a member of the plant kingdom, the microalga Ostreococcus tauri. Biochem. J. 2005, 389, 483-490. [CrossRef] [PubMed]

(C) 2019 by the authors. Licensee MDPI, Basel, Switzerland. This article is an open access article distributed under the terms and conditions of the Creative Commons Attribution (CC BY) license (http://creativecommons.org/licenses/by/4.0/). 